\title{
MAKNA SIMBOLIK DALAM BAHASA RITUAL REBA PADA MASYARAKAT LUBA DESA TIWORIWU KECAMATAN JEREBUU KABUPATEN NGADA
}

\author{
Pelipus Wungo Kaka \\ Dosen PGSD STKIP Citra Bakti \\ e-mail: filipwungokaka@gmail.com
}

\begin{abstract}
ABSTRAK
Penelitian ini bertujuan untuk mendeskripsikan tata cara pelaksanaan upacara Reba dalam budaya masyarakat Kampung Luba Desa Tiworiwu Kecamatan Jerebuu Kabupaten Ngada, mendeskripsikan makna simbol-simbol bahasa ritual Reba di Desa Tiworiwu. Manfaat penelitian ini adalah sebagai bahan masukan bagi masyarakat Luba dalam memaknai nilai-nilai upacara ritual Reba, sebagai bahan untuk memperkaya kekhasan kearifan lokal bangsa sebagai suatu nilai luhur yang dianut oleh masyarakat Ngada pada umumnya dan masyarakat Luba Desa Tiworiwu pada khususnya, sebagai bahan informasi bagi peneliti lain yang ingin mengkaji lebih lanjut masalah yang berkaitan dengan penelitian ini, sebagai informasi untuk membangkitkan dan menumbuhkan rasa cinta kearifan lokal lokal. Penelitian ini bersifat deskriptif kualitatif yaitu suatu analisis yang menggambarkan secara rinci hasil-hasil temuan di lapangan yang menggunakan pertanyaan-pertanyaan. Penelitian ini menggunakan teknik pengumpulan data yaitu dengan mewawancarai dan mengobservasi. Teknik analisis data yang digunakan adalah deskriptif kualitatif. Hasil penelitian menunjukkan bahwa dalam upacara ritual Reba pada masyarakat Luba Desa Tiworiwu Kecamatan Jerebuu mempunyai tata cara atau pelaksanaan yang dilakukan pada saat upacara ritul Reba seperti didalam nilai-nilai tersebut antara lain: nilai religius, nilai filosofis, nilai kesenian, nilai moral, nilai magis, nilai ekonomi, nilai sosial, nilai hukum,dan nilai pendidikan.Ritual Reba merupakan sebuah acara yang patut dilaksanakan selama setahun sekali perlu ditaati sejak dari leluhur pada zaman dahulu kala dan harus terbawa terus sampai anak cucu. Apabila disia-siakan ritual Reba ini maka segala usaha tidak terkabul oleh perlindungan leluhur karena leluhur inilah yang membentuk budaya adat ritual Reba sehingga dikembangkan oleh generasi penerus. Dengan adanya upacara Reba dapat mengingatkan pesanan yang telah ditinggalkan oleh leluhur (Sili Ana Wunga) sebagai pioner pertama penyelenggara budaya Reba. Perayaan adat Reba merupakan upacara ritual magis karena seluruh tahapan upacara Reba wajib didahului dengan pemberian sesajian Roh arwah leluhur agar dapat menguasai alam sehingga perayaan Reba dapat berjalan dengan baik.

Kata Kunci: Makna Simbolik Bahasa Ritual Reba
\end{abstract}

\section{ABSTRACT}

The background of this research is very important for the community as a ritual ceremony Luba Reba embrace the values of the humanitarian nature that need to be maintained for the younger generations are relevant to the procedures established by the ancestral ceremonies. With the ritual Reba, Luba people still believe in good faith that is not extinct and still retain its own culture and do not care about foreign cultures. The purpose of this study is to describe procedures for Reba ceremony in the village of Luba culture Tiworiwu Jerebuu Ngada District, describes the meaning of symbols in a ceremony at Village Tiworiwu Reba. The benefits of this 
research is as an input for the Luba in meaning values Reba ritual ceremonies, as a material to enrich the cultural distinctiveness of the nation as a virtue embraced by the community and society in general Ngada Luba Village Tiworiwu in particular, for information for researchers others who wish to further examine the problems associated with this research, as information to generate and foster a love of local culture. This study is a qualitative descriptive analysis that describes in detail the findings in the field who use the questions. This study uses data collection techniques that is by interviewing and observing. Data analysis technique used is descriptive qualitative. The results showed that in the ritual ceremony at the Luba Village Reba Tiworiwu Jerebuu District has procedures or operations to be carried during the ceremony ritual Reba like in those values among others: the religious, philosophical values, artistic values, moral values, the magical , economic value, social value, legal value, and value education. Reba ritual is an event that should be implemented over a year since it need to be adhered to from ancestors in ancient times and must be carried on until our children and grandchildren. If the ritual Reba wasted this then all the effort is not granted by the ancestors for protection of ancestral indigenous culture that has shaped so that Reba rituals developed by future generations. With the ceremony to remind Reba orders that have been left by the ancestors (Sili Ana Wunga) as the first pioneer of cultural organizers Reba. Reba is the customary celebration of a magical ritual for all phases of the ceremony must be preceded by Reba Spirit giving offerings to ancestral spirits can control nature so that the celebration of Reba can run well.

Keywords: symbolic language meaning of the ceremony Reba

PENDAHULUAN

Indonesia adalah Negara

majemuk yang beraneka ragam

suku, Ras dan kebudayaan.

Dalam kehidupan yang

beranekaragam itu terdapat

unsur-unsur yang bernilai tinggi,

karena itu diperlukan upaya untuk menjaga dan melestarikan secara historis kebudayaan. Kebudayaan warisan nenek moyang yang didalamnya terkandung nilai-nilai luhur, yang terdiri dari keanekaragaman kebudayaan suatu bangsa yang mengandung unsur persamaan yang secara cultural menjadi alat pemersatu tradisi gotong royong pendiri monument

mengalitik, penggarapan lahan, seni ritual, teknologi dan lain sebagainya. (Depdikbud,1989:20). Agar warisan tidak punah maka sebagai generasi penerus, pewaris kebudayaan bangsa harus menggali dan mengkaji nilai-nilai kebudayaan yang ditinggalkan oleh nenek moyang kita, untuk itu berbagai upaya pelestarian kebudayaan di Indonesia telah diusahakan oleh pemerintah dengan suatu harapan agar kebudayaan yang ada di Indonesia tetap menunjukan identitasnya yang utuh. Pernyataan ini dalam batang tubuh UUD 1945 yaitu 
pasal 32 ayat (1) yang berbunyi: “ Negara memajukan kebudayaan nasional Indonesia di tengah peradaban dunia dengan menjamin kebebasan masyarakat dalam memelihara dan mengembangkan nilai-nilai budaya". Hal ini secara tegas menunjukkan bahwa pemerintah berkewajiban untuk memelihara dan melestarikan serta mengembangkan kebudayaan Nasional melalui program program yang telah di tetapkan. Sebagai warga negara yang menganut dan menjunjung tinggi bahwa betapa pentingnya nilainilai kebudayaan daerah yang ada di Indonesia maka patut diterapkan dalam kehidupan bermasyarakat.

Menurut Suparlan (1983:5) ada tiga cara dalam mempelajari sejarah : (1) Melalui pengalaman hidup dalam lingkungan sehingga dari pengalaman itu dapat memiliki suatu tindakan yang sesuai dengan lingkungan yang dihadapi dan keinginan yang akan dicapai. (2) Melalui pengalaman dalam kebudayaan sosial. (3) Melalui petunjuk- petunjuk simbolis atau melalui komunikasi simbolik.

Dari ketiga hal di atas, maka upacara Reba di Desa
Tiworiwu I merupakan salah satu kebudayaan yang perlu dilestarikan oleh penduduknya. Reba sebagai ritual budaya masyarakat Ngada seperti yang telah dirumuskan oleh Paul Arndt dalam Demu Tua Yosep, (1954:12) bahwa upacara Reba merupakan pesta perkawinan, pesta panen, pesta tahun baru adat dan pesta solidaritas antar kekeluargaan, agar tetap mempertahankan warisan leluhur yang dikembangkan oleh generasi-generasi penerus. Dengan adanya upacara Reba dapat mengingatkan pesanan yang telah ditinggalkan oleh leluhur (Sili Ana Wunga) pioner pertama penyelenggara budaya Reba atau peletak dasar perayaan adat Reba yang merupakan upacara ritual magis karena seluruh tahapan atau rangkaian upacara Reba harus didahului dengan pemberian sesajian bagi roh arwah leluhur agar dapat menguasai alam sehingga perayaan Reba dapat berlangsung dengan baik atau relevan.

Dalam upacara Reba akan dirayakan sesuai dengan Kalender Reba, khususnya pada masyarakat Luba Desa Tiworiwu, 
upacara Reba dirayakan setahun sekali pada setiap bulan Pebruari. Dalam upacara Reba terdapat tiga tahap perayaan inti, yaitu : Kobe dheke, Sedo Uwi dan Su'i Uwi. Dimana Kobe dheke artinya masuk rumah adat, Sedo Uwi artinya tarian adat dan Su'i Uwi artinya penutup acara Reba. Apabila antara ketiga tahap perayaan inti tersebut ada yang sengaja melanggar, maka orang tersebut akan ditimpa musibah atau terbentur dari Roh leluhur. Keterangan di atas, menunjukkan bahwa Ritual Reba termasuk dalam wujud kompleks aktivitas kelakukan berpola dari manusia yang terkandung di dalamnya, sangat berkaitan erat dengan aspek ekonomi sosial, dan keagamaan yang ada pada masyarakat dan mampu dalam kehidupan masyarakat. Reba adalah fenomen keagamaan dan merupakan sebuah ritus agama asli yang dirayakan setiap tahun oleh suku Ngada. Ritus keagamaan ini yang ditayangkan selama beberapa hari berturutturut sangat diwarnai dengan doa dan kurban, sebuah upacara yang begitu kaya baik dari segi isi maupun dari segi bentuk-bentuk simbolnya, sungguh-sungguh menoreh religiositas orang Ngada. Reba merupakan perayaan terbesar baik dalam makna maupun dalam penampilan lahiriahnya.

Simbol utama dari ritus Reba ini adalah "Uwi/Ubr" yang diyakini sebagai roti kehidupan manusia pada masa "in Illo temporenya "orang Ngada (Domi Waso 2010:181) Ubi yang dipanggil namanya dan dipuji-puji pada perayaan Reba merupakan personifikasi seorang tokoh mitologis perempuan, seorang utusan Tuhan bagi manusia dan secara khusus lagi pribadi yang mati karena mengurbankan hidupnya agar sesamanya dapat hidup sejahtera. Penempatan perayaan Reba yang terbentang dari Akhir Pebruari sampai pada akhir Februari dan pada musim hujan mau menyatakan bahwa perayaan Reba ini bermakna sebagai syukur atas penyelenggaraan "Dewa zeta Nitu zale" pada tahun silam dan mohon pendampingannya pada tahun yang akan datang. Reba merupakan perayaan keluarga karena dirayakan oleh seluruh keluarga, sebuah perayaan yang 
memiliki dampak sistemik yang luas karena apa yang dirayakan pada saat Reba memang mempengaruhi pesta adat lainnya. Reba sebagai ritus keagamaan orang Ngada, baik dari segi mitologinya maupun dari tahaptahap pelaksanaannya selalu berbicara mengenai kehidupan secara menyeluruh tidak hanya mengenai segi tertentu saja.(Jawa Maku 2000:1).

Reba secara tekstual memiliki paling kurang lima arti: Kaju Reba, adat Reba, larangan seperti "Reba bheto" atau larangan memotong bambu, sikap tidak konsisten, dan situasi sulit dilematis yang tidak didugaduga.(Paul Arndt 1961:454). Reba yang menjadi tema kita adalah arti kedua yaitu "adat atau buku gua Reba". II Ritus Reba tidak dirayakan secara serempak karena adat Reba ini tergantung dari petunjuk "kepo wesu" atau pemegang adat yang menentukan masa perayaannya di sebuah wilayah berbasis pada kalender adat yang disebut "tahun sobhi"(tahun sisir) (Domi Waso 2010:184). Meskipun waktu pelaksanaannya berbeda-beda struktur perayaan Reba umumnya diterima memiliki tiga tahap utama: pertama:Kobe Dheke, Kedua: Kobe dhoi, Ketiga: kobe Sui.

Tiga tahap konsekutip ini tidak sangat ketat karena ada wilayah yang tahap ketiga didahulukan menjadi tahap kedua. Yang penting dan yang tidak boleh dilupakan adalah bahwa dalam tiga tahap ini tertera sungguh-sungguh rancangbangun totalitas hidup dan kepribadian mereka sebagai manusia Ngada. Tahap pertama Kobhe Dheke disebut pula sebagai saat kembali ke rumah induk (Sao Puu), semua anggota suku yang berasal dari rumah-rumah yang mekar dari rumah induk (sao dhoro) dan yang mencari hidup di mana saja (Gae kuru nguza nee wae lina) diharapkan semua datang dan masuk ke dalam rumah Induk atau rumah pokok ini. Mereka kembali bersama-sama untuk menghormati leluhur asali mereka (Beo Ine dheqa ema).

Peristiwa kembali ke rumah Induk ini sebetulnya merupakan upaya membangun kesadaran bahwa mereka semua berada dalam perlindungan leluhur asal, yang selalu disapa dengan istilah "cine-cema" atau "dewa sao" ketika mereka berada dalam rumah 
Induk. Gambaran "Dewa Sao" merupakan gambaran Allah yang dekat, akbar sekaligus akrab, Allah imanen, sebutan atau panggilan akrab dari "Dewa Wawo". Lupa rumah Induk akan membawa petaka aneka wajah bagi keluarga bersangkutan. Musibah yang menimpa disebut sebagai akibat dari kelalaian "rebho sao puu"(lupa rumah induk). Tahap kedua Kobe dhoi ditandai dengan acara pengangkatan ubi/uwi tinggi-tinggi disertai teriakan "be uwi"(hai ubi) dan diulangi oleh mereka yang hadir sebanyak tiga kali. Pada tahap kedua ini ubi tampil dalam bentuk "koba"( atau batang menjalar ubi)" yang dililitkan pada "sua atau tofa" yang biasanya diletakan di mataraga atau tempat sakral di dalam rumah Induk. Pada malam kedua ini mulailah tandak yang dikenal sebagai "O uwi" sebuah tandak bersama dalam bentuk lingkaran, yang sampai sekarang ini merupakan tarian yang populer, yang masih memiliki daya pikat untuk mengundang, memanggil semua sahabat untuk dapat berpartisipasi dalam tarian persekutuan itu. Ubi (Uwi) yang menjadi refrain lagu dalam tarian ini adalah simbol dari anugerah kehidupan yang harus disyukuri secara bersama-sama dalam tarian yang berbentuk lingkaran, simbol persekutuan dan persaudaraan. Tarian "o uwi" dalam bentuk lingkaran di tengah kampung ini (kisa nata) biasanya di awali dengan teriakan "wuku uwi atau pujian ubi":" o uwi e, uwi meze go lewa laba, kutu koe koe ano koe, sui moki-moki bhai moli, koba rako lizu lado wai poso"(Ubi sebesar Gong, setinggi tambur,biarpun disungkur oleh babi hutan, ubinya tak pernah habis, biarpun digali oleh babi landak,ubinya tetap ada, tonggaknya harus setinggi gunung, merambatnya sampai ke langit)".Tahap ketiga,Kobe Sui, merupakan tahap dimana orang Ngada di dalam rumah adat melaksanakan beberapa agenda seperti: sui uwi, Su bu sua, bura sua dan lese dhe nee peda pawe (Pata Dela).

Dalam "sui Uw" mereka menyimak kembali ziarah perjalanan mereka menuju tanah Ngada sekarang ini, dan dalam ziarah itu direnungkan kekuatan serta keterbatasan mereka, kerja keras mereka, siapa saja yang menjadi mitra dalam ziarah tersebut, panggilan serta perutusan 


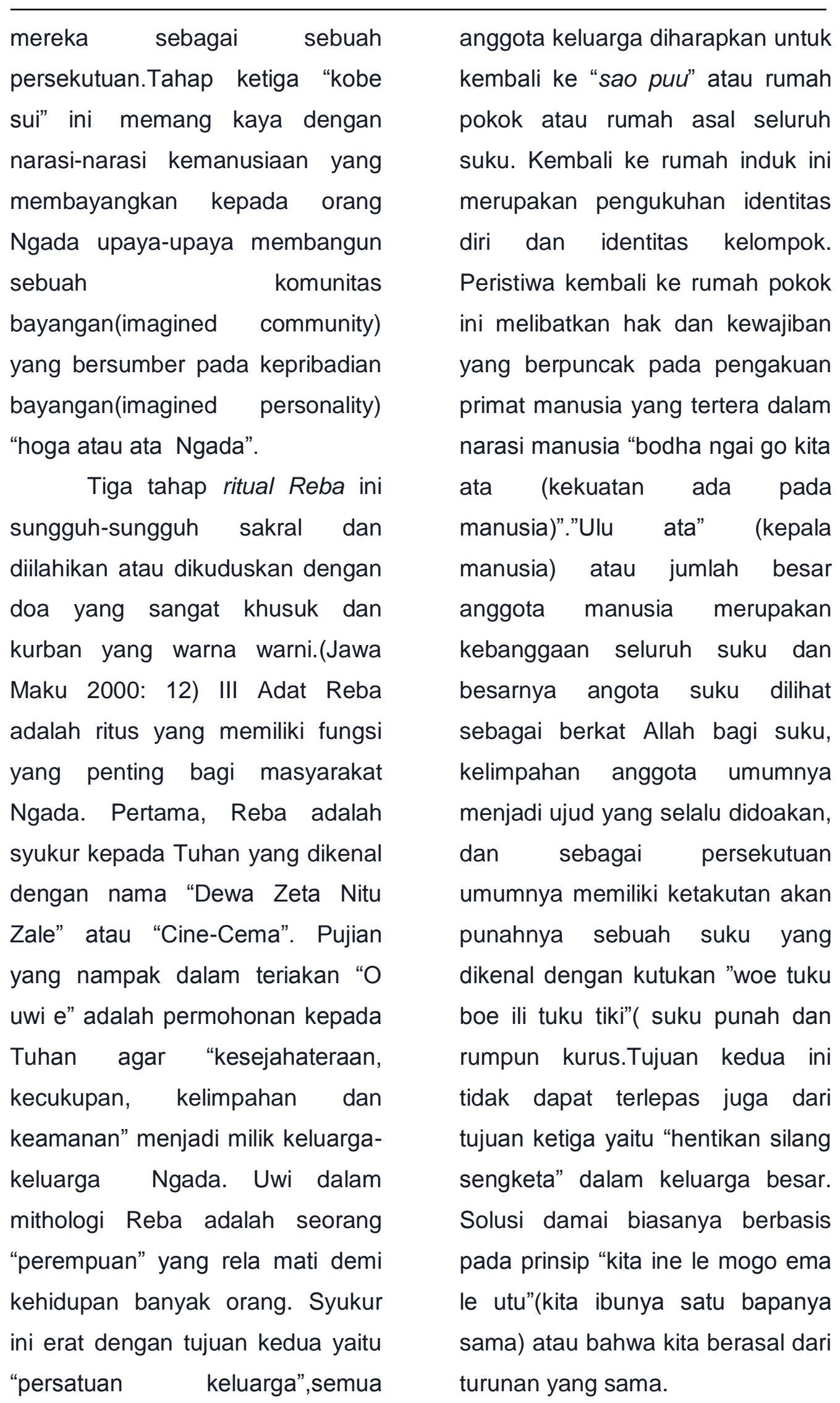




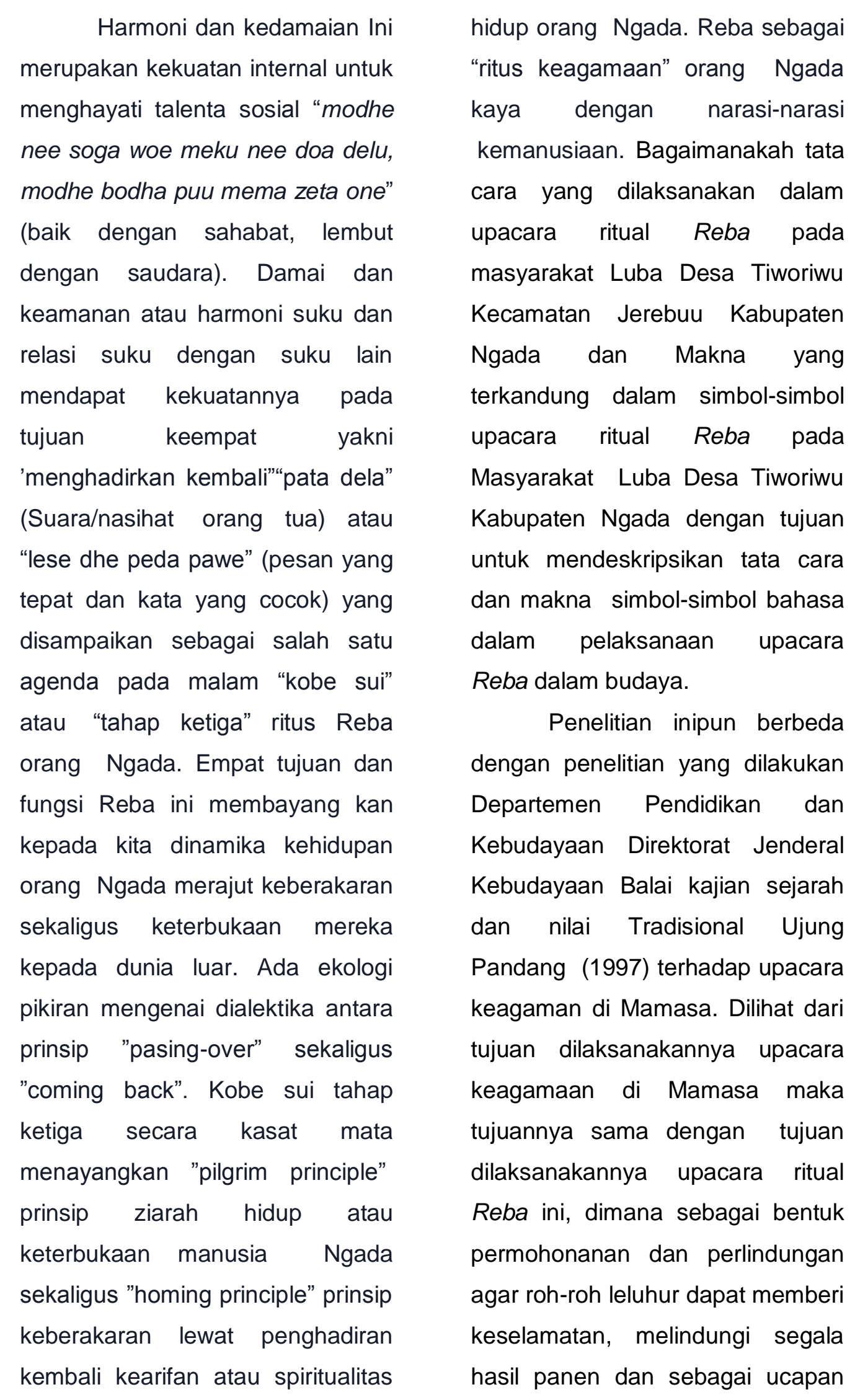


syukur kepada para leluhur akan keberhasilan selama setahun. Akan tetapi memiliki perbedaan pada masalah yang diteliti dengan penelitian dari upacara ritual Reba ini. Apabila penelitian upacara keagamaan ini diteliti tentang seluk beluk, dan arti simbolik yang terkandung dalam upacara ini, maka penelitian ini meneliti tentang bagaimana tata cara dan arti simbol-simbol yang terkandug dalam upacara ritual Reba ini. Untuk memahami suatu konsep dasar yang akan dikembangkan dalam suatu penulisan selanjutnya penulis lebih menekankan pada konsep dasar tentang kebudayaan upacara ritual Reba, dan makna bahasa adat sebagai simbolik dalam upacara Reba sebagai dasar dalam menunjang penulis untuk mengangkat suatu permasalahan.

Menurut Koentjaraningrat, (19:86) mendefenisikan kebudayaan sebagai suatu keseluruhan sistem gagasan dan hasil karya manusia beserta keseluruhan dari hasil budaya dan karya manusia yang dibiasakan dengan belajar. Senada dengan pendapat di atas, Shadiliy (Bagul Dagul, 1984:81) mengatakan bahwa budaya adalah : keseluruhan warisan sosial yang dapat dipandang sebagai karya yang tersusun menurut tata tertib teratur, biasanya terdiri dari kebendaan, kemahiran, teknik, pikiran dan gagasan serta nilai-nilai tertentu. Hal tersebut, berarti bahwa hampir seluruh tindakan manusia adalah "kebudayaan karena hanya amat sedikit tindakan manusia dalam rangka kehidupan masyarakat yang tak perlu dibiasakan dengan belajar yaitu hanya beberapa tindakan naluri, beberapa refleksi, beberapa tindakan akibat proses fisiologi atau berkelakuan tidak sopan.

$$
\text { Menurut Djojodigoeno, }
$$
(1958 : 28) Berbudaya adalah “ daya dari budi yang berupa cipta, karsa, dan rasa. Cipta adalah kerinduan manusia untuk mengetahui rahasia dari segala hal yang ada dalam pengalamannya, yang meliputi pengalaman lahir dan batin. Hasil cipta berupa berbagai ilmu pengetahuan yang bersumber pada kenyataan yang ada. Karsa adalah kerinduan manusia untuk menginsafi, yakni darimana manusia itu sebelum lahir dan kemana manusia sesudah mati, rasa adalah 
kerinduan manusia akan

keindahan sehingga menimbulkan dorongan baginya untuk menikmati keindahan.

Dalam hubungannya dengan penelitian ini yang menjadi hasil cipta dari budaya atau wujud dari budaya atau "daya dari budi yang berupa cipta" pada masyarakat Desa Tiworiwu adalah upacara ritual Reba. Upacara ini sebagai salah satu wujud hasil cipta budaya dan bukan sebagai ilmu pengetahuan, akan tetapi ia sebagai objek kajian suatu ilmu pengetahuan bila diteliti secara ilmiah. Oleh karena itu, penulis membuat suatu kesimpulan bahwa setiap hasil cipta dan budaya itu jika dipelajari, selalu diamati, diteliti secara ilmiah atau meteodologis maka dapat dikatakan hasil cipta buadaya itu berupa ilmu pengetahuan.

Menurut Selo Soemardjan dan Soeleman Soemardi ( Koentjaraningrat, $1990:$ 179) Kebudayaan dikatakan sebagai sebuah hasil karya, rasa, dan cipta masyarakat. Karya menghasilkan tekhnologi kebendaan atau kebudayaan jasmaniah (Material kultur) yang diperlukan manusia untuk menguasai alam semesta agar kekuatan serta hasilnya dapat diabadikan pada keperluan masyarakat. Rasa meliputi jiwa manusia yang mewujudkan kaidahkaidah dan nilai-nilai kemasyarakatan yang perlu untuk mengatur masalah-masalah kemasyarakatan dalam arti luas. Cipta merupakan kemampuan mental, kemampuan berpikir dari orang-orang yang hidup bermasyarakat yang antara lain menghasilan filsafat serta ilmu pengetahuan baik yang berwujud teori murni maupun yang telah disusun untuk langsung diterapkan dalam kehidupan bermasyarakat. Dalam hubungan dengan penelitian ini, sependapat dengan Selo Soemardjan,dkk, yang mengatakan bahwa kebudayaan dikatakan sebagai sebuah hasil karya, rasa dan cipta masyarakat. Penulis ingin mengaitkan ketiga aspek budaya dari penelitian ini, karya adalah kebudayaan jasmaniah (material kultural), yakni upacara ritual Reba, yang dilakukan karena diperlukan oleh masyarakat Luba sebagai bentuk dari hubungan antara arwah nenek moyang dan generasi-generasi masyarakat Luba agar terhindar dari malapetaka. Rasa meliputi jiwa 
manusia yang meliputi kaidahkaidah dan nilai-nilai. Dari upacara inipun mengandung nilai-nilai dan kaidah-kaidah bahasa daerah yang harus diperhatikan oleh penyair. Syair dalam bahasa adat ini, tidak semua orang mahir untuk bersyair ritual Reba karena sifatnya mengarang dan menimbulkan resiko bagi oknum tersbut. Reba merupakan perayaan terbesar baik dalam makna maupun dalam penampilan lahiriahnya. Dalam perayaan Reba ini kita dapat menemukan secara kasat mata rancangbangun religiositas orang Ngada, rancangbangun relasi manusia dengan Tuhan, dengan sesama manusia dan dengan lingkungan hidupnya. Simbol utama dari ritus Reba ini adalah "Uwi/Ubi" yang diyakini sebagai roti kehidupan manusia pada masa "in Illo temporenya "orang Ngada (Domi Waso 2010:181) Ubi yang dipanggil namanya dan dipuji-puji pada perayaan Reba merupakan personifikasi seorang tokoh mitologis perempuan, seorang utusan Tuhan bagi manusia dan secara khusus lagi pribadi yang mati karena mengurbankan hidupnya agar sesamanya dapat hidup sejahtera. Penempatan perayaan Reba yang terbentang dari Akhir Pebruari sampai pada akhir Februari dan pada musim hujan mau menyatakan bahwa perayaan Reba ini bermakna sebagai syukur atas penyelenggaraan "Dewa zeta Nitu zale" pada tahun silam dan mohon pendampingannya pada tahun yang akan datang. Reba merupakan perayaan keluarga karena dirayakan oleh seluruh keluarga, sebuah perayaan yang memiliki dampak sistemik yang luas karena apa yang dirayakan pada saat Reba memang mempengaruhi pesta adat lainnya. Reba sebagai ritus keagamaan orang Ngada, baik dari segi mitologinya maupun dari tahaptahap pelaksanaannya selalu berbicara mengenai kehidupan secara menyeluruh tidak hanya mengenai segi tertentu saja (Jawa Maku 2000:1). Reba secara tekstual memiliki paling kurang lima arti: Kaju Reba, adat Reba, larangan seperti "Reba bheto" atau larangan memotong bambu, sikap tidak konsisten, dan situasi sulit dilematis yang tidak diduga-duga (Paul Arndt 1961:454). Reba ini tergantung dari petunjuk "kepo wesu" atau pemegang adat yang 
menentukan masa perayaannya di sebuah wilayah berbasis pada kalender adat yang disebut "tahun sobhi"(tahun sisir) (Domi Waso 2010:184).Meskipun waktu pelaksanaannya berbeda-beda struktur perayaan Reba umumnya diterima memiliki tiga tahap utama: pertama: Kobe Dheke, Kedua: Kobe dhoi, Ketiga: kobe Sui. Tiga tahap konsekutip ini tidak sangat ketat karena ada wilayah yang tahap ketiga didahulukan menjadi tahap kedua. Yang penting dan yang tidak boleh dilupakan adalah bahwa dalam tiga tahap ini tertera sungguh-sungguh rancangbangun totalitas hidup dan kepribadian mereka sebagai manusia Ngada. Tahap pertama Kobe Dheke disebut pula sebagai saat kembali ke rumah induk (Sao Puu), semua anggota suku yang berasal dari rumah-rumah yang mekar dari rumah induk (sao dhoro) dan yang mencari hidup di mana saja (Gae kuru nguza nee wae lina) diharapkan semua datang dan masuk ke dalam rumah Induk atau rumah pokok ini.Mereka kembali bersama-sama untuk menghormati leluhur asali mereka (Beo Ine dheqa ema). Peristiwa kembali ke rumah Induk ini sebetulnya merupakan upaya membangun kesadaran bahwa mereka semua berada dalam perlindungan leluhur asali, yang selalu disapa dengan istilah "cine-cema" atau "dewa sao" ketika mereka berada dalam rumah Induk. Gambaran "Dewa Sao"merupakan gambaran Allah yang dekat, akbar sekaligus akrab, Allah imanen, sebutan atau panggilan akrab dari "Dewa Wawo". Lupa rumah Induk akan membawa petaka aneka wajah bagi keluarga bersangkutan.

Musibah yang menimpa disebut sebagai akibat dari kelalaian "rebho sao puu"(lupa rumah induk). Tahap kedua Kobe dhoi ditandai dengan acara pengangkatan ubi/uwi tinggi-tinggi disertai teriakan "be uwi"(hai ubi) dan diulangi oleh mereka yang hadir sebanyak tiga kali. Pada tahap kedua ini ubi tampil dalam bentuk "koba" (atau batang menjalar ubi)" yang dililitkan pada "sua atau tofa" yang biasanya diletakkan di mataraga atau tempat sakral di dalam rumah Induk. Pada malam kedua ini mulailah tandak yang dikenal sebagai "O uw" sebuah tandak bersama dalam bentuk lingkaran, yang sampai sekarang ini merupakan tarian 
yang populer, yang masih memiliki daya pikat untuk mengundang, memanggil semua sahabat untuk dapat berpartisipasi dalam tarian persekutuan itu. Ubi (Uwi) yang menjadi refrain lagu dalam tarian ini adalah simbol dari anugerah kehidupan yang harus disyukuri secara bersama-sama dalam tarian yang berbentuk lingkaran, simbol persekutuan dan persaudaraan. Tarian "O uw" dalam bentuk lingkaran di tengah kampung ini (kisa nata) biasanya di awali dengan teriakan "wuku uwi atau pujian ubi":" o uwi e, uwi meze go lewa laba, kutu koe koe ano koe, sui moki-moki bhai moli, koba rako lizu lado wai poso" (Ubi sebesar Gong, setinggi tambur,biarpun disungkur oleh babi hutan, ubinya tak pernah habis, biarpun digali oleh babi landak, ubinya tetap ada, tonggaknya harus setinggi gunung, merambatnya sampai ke langit)". Tahap ketiga, Kobe Sui, merupakan tahap dimana orang Ngada di dalam rumah adat melaksanakan beberapa agenda seperti: sui uwi, Su bu sua, bura sua dan lese dhe nee peda pawe (Pata Dela). Dalam "sui Uwi" mereka menyimak kembali ziarah perjalanan mereka menuju tanah
Ngada sekarang ini, dan dalam ziarah itu direnungkan kekuatan serta keterbatasan mereka, kerja keras mereka, siapa saja yang menjadi mitra dalam ziarah tersebut, panggilan serta perutusan mereka sebagai sebuah persekutuan. Tahap ketiga "kobe sui' ini memang kaya dengan narasi-narasi kemanusiaan yang membayangkan kepada orang Ngada upaya-upaya membangun sebuah komunitas bayangan (imagined community) yang bersumber pada kepribadian bayangan (imagined personality) "hoga atau ata Ngada".

Tiga tahap ritus Reba ini sungguh-sungguh sakral dan diilahikan atau dikuduskan dengan doa yang sangat khusuk dan kurban yang warna warni. Jawa Maku (2000: 12) Adat Reba adalah ritus yang memiliki fungsi yang penting bagi masyarakat Ngada. Pertama, Reba adalah syukur kepada Tuhan yang dikenal dengan nama "Dewa Zeta Nitu Zale" atau "Cine-Cema". Pujian yang nampak dalam teriakan "O uwi e" adalah permohonan kepada Tuhan agar "kesejahateraan, kecukupan, kelimpahan dan keamanan" menjadi milik keluarga- 
keluarga Ngada. Uwi dalam mithologi Reba adalah seorang "perempuan" yang rela mati demi kehidupan banyak orang. Syukur ini erat dengan tujuan kedua yaitu "persatuan keluarga",semua anggota keluarga diharapkan untuk kembali ke "sao puu" atau rumah pokok atau rumah asal seluruh suku. Kembali ke rumah induk ini merupakan pengukuhan identitas diri dan identitas kelompok. Peristiwa kembali ke rumah pokok ini melibatkan hak dan kewajiban yang berpuncak pada pengakuan primat manusia yang tertera dalam narasi manusia "bodha ngai go kita ata (kekuatan ada pada manusia)". "Ulu ata" (kepala manusia) atau jumlah besar anggota manusia merupakan kebanggaan seluruh suku dan besarnya angota suku dilihat sebagai berkat Allah bagi suku, kelimpahan anggota umumnya menjadi ujud yang selalu didoakan, dan sebagai persekutuan umumnya memiliki ketakutan akan punahnya sebuah suku yang dikenal dengan kutukan "woe tuku boe ili tuku tiki" ( suku punah dan rumpun kurus.

Tujuan kedua ini tidak dapat terlepas juga dari tujuan ketiga yaitu "hentikan silang sengketa" dalam keluarga besar. Solusi damai biasanya berbasis pada prinsip "kita ine le mogo ema le utu" (kita ibunya satu bapanya sama) atau bahwa kita pasingover" sekaligus "coming back" berasal dari turunan yang sama. Harmoni dan kedamaian Ini merupakan kekuatan internal untuk menghayati talenta sosial "modhe nee soga woe meku nee doa delu, modhe bodha puu mema zeta one"(baik dengan sahabat, lembut dengan saudara). Damai dan keamanan atau harmoni suku dan relasi suku dengan suku lain mendapat kekuatannya pada tujuan keempat yakni 'menghadirkan kembali'"'pata dela"(Suara/nasihat orang tua) atau "lese dhe peda pawe"(pesan yang tepat dan kata yang cocok) yang disampaikan sebagai salah satu agenda pada malam "kobe sui" atau "tahap ketiga" ritus Reba orang Ngada.

Empat tujuan dan fungsi Reba ini membayang kan kepada kita dinamika kehidupan orang Ngada merajut keberakaran sekaligus keterbukaan mereka kepada dunia luar. Ada ekologi pikiran mengenai dialektika antara prinsip "Kobe sui tahap ketiga 
secara kasat mata menayangkan "pilgrim principle" prinsip ziarah hidup atau keterbukaan manusia Ngada sekaligus "homing principle" prinsip keberakaran lewat penghadiran kembali kearifan atau spiritualitas hidup orang Ngada. Reba sebagai "ritus keagamaan" orang Ngada kaya dengan narasinarasi kemanusiaan. Narasi kemanusiaan seperti tertera dalam "pata dela" (Suara Leluhur) dan kearifan "lese dhe peda pawe" (pesan yang tepat dan bandingan yang cocok) umumnya mengusung dekalog atau sepuluh prinsip pedoman hidup manusia Ngada yang dalam kenyataannya menjadi kekuatan dalam rancangbangun "imagined personality" dan "imagined community" orang Ngada. Dekalog filsafat hidup orang Ngada itu adalah: pertama: Dewa Zeta Nitu Zale, kedua : Bodha Molo Ngata Go Kita Ata, ketiga ; Dhepo Da Beo Tedu Da Bepu, keempat: Dhudzu Puru Nee Nama Raka, kelima ; Dua Wi Uma Nuka Wi Sao, enam ;Modhe Nee Xoga Woe Meku Nee Doa Delu, ketujuh : Maku Nee Da Fai Walu, Kaqo Nee Da Ana Salo, kedelapan: Go Ngata Go Ngata, Go Tenge Go Tenge, kesembilan:
Kedhu Sebu Pusi Sebu, kesepuluh : Bugu Kungu Nee Uri Logo. Dari sepuluh narasi ini merupakan indikator moralitas kepribadian dan merupakan elemen yang menentukan jati diri beradab "ata Ngada" atau orang Ngada , sebuah "religious capital" yang dalam kehidupan masyarakat berkembang menjadi kekuatan atau "spiritual capital" bagi orang Ngada. Ketika "religious capital" menjadi kekuatan dan pengaruh bagi masyarakat maka "religious capital" berubah menjadi "spiritual capital". Siritual capital adalah dampak sosial dari "religious capital". (Anton Bele 2012: 51) Sepuluh narasi filsafat hidup ini adalah roh atau pedoman yang harus dipegang oleh orang $\mathrm{Ngada}$ dimana saja dia berada.

\section{Orang}

Bajawa menyebutnya sepuluh prinsip hidup ini "waka" (Roh,semangat,nyali). Orang Ngada dapat bersyair ria“" go waka kita da dhada dhu da laa dada, kita da pero dhu da laa ezo"( Roh ini akan saya bawa pada saat saya berjalan jauh, saya simpan pada saat ketika saya merantau"). Kemana saja saya pergi pedoman hidup inilah kekuatan saya. Dari dekalog filsafat hidup ini lahirlah 
Sembilan (9) tahap internalisasi nilai-nilai rohani manusia Ngada sebagai berikut:

Kesiapan/kewaspadaan

(Gera geta); (2) praktek penegakan hukum (adha gua); (3) sikap cermat/teliti (getu-getu); (4) rajin dan efisien dalam usaha (gutu gata); (5) mampu berbagi dengan sesama (gima ngima) dalam komunitas; (6) ada dan menjadi terang di wilayah publik ( molo moe ila wolo); (7) cerdas dan pekah bersyukur kepada Tuhan, sesama dan alam dunia (po pake), (8) berjuang hidup tanpa kekerasan yang melampaui kekerasan batu (ate wae tolo watu); (9) lemah lembut dan rendah hati di hadapan Tuhan dan sesame (pegu melu). Watu Y. Vianey (2010: 155) Ritus Reba seperti yang sudah kita cermati di atas ini, memang kaya dengan doa yang khusuk dan kurban persembahan yang warna warni. Yang merupakan ekspresi iman mereka kepada Allah yang akbar (dewa wawo) sekaligus akrab (Dewa Sao). Sangat kasat mata doa-doa ritual orang Ngada selama Reba menampilkan representasi ilahi yang diadik sekaligus triadic (Watu Y.Vianey 2011:161).
Dalam doa-doa mereka Allah disapa dengan nama (1) IneEma, yaitu Tuhan sebagai lbu sekaligus Bapa, (2) Susu Keri Ase kae, yaitu Tuhan sebagai pemberi kasih tak berhingga sekaligus pengambil kasih yang tak terduga. (3) "Dewa Zeta Nitu Zale, yaitu Tuhan sebagai yang transenden sekaligus imanen. Selanjutnya dalam representasi citraan llahi yang triadik, Yang Sakral disapa dengan nama berikut, 1) Dewa saga telu yaitu Tuhan yang triadik dalam nama "Dewa Wawo, Dewa Sao dan Dewa jao dan (2) Tuhan sebagai Yang awal (mori puu), yang turun terlibat, dan yang akhir, yang tersembunyi dalam kesadaran marginal para penganutnya karena pada saat Reba semua yang berasal dari "Sao Puu, Sao Dhoro dan Sao Lobo" berkumpul sebagai keluarga besar. Dalam doa-doa ini cukup jelas bahwa Allah orang Ngada secara literal memang tidak menerima Allah yang hanya dipanggil sebagai "bapa" yang berpotensi memperkuat patriarki atau hanya sebagai "ibu" yang bisa memperkuat matriarkhi dalam kehidupan sosial di tengah dunia. Tafsiran diadik dan triadik ini 
mempunyai implikasi positif terhadap gerakan emansipasi anti diskriminasi sosial berbasis jender. Watu.Y.Vianey (2010:158) Dalam ritus keagamaan Reba ada doa yang didaraskan secara internal dalam rumah maupun secara publik di luar rumah. Dalam doa yang menjadi elemen utama dalam tahap-tahap adat Reba itu hadir bahasa keagamaan yang bercitra naratif-memoratif. Ada beberapa hal yang dapat kita utarakan dalam kaitan dengan doa-doa lisan selama perayaan Reba orang Ngada. Doa selama "Reba" sepertinya

mempertanggungjawabkan

pandangan mereka tentang manusia karena pandangan mereka mengenai Allah dan konsep mereka mengenai manusia berkorelasi secara intensif. Bagaimana mereka mengenal Allah dan memahami Allah mempunyai konsekwensinya pada pemahaman dan pendekatan terhadap manusia. Pengalaman akan manusia juga berpengaruh terhadap konsep mereka tentang Allah. (Budi Kleden 2011: 179) Allah orang Ngada yang digelar sebagai "Mori su beo nee tada naa" (Sang mahatahu) berdampak pada konsep atau pemahaman orang Ngada tentang manusia yang hidupnya warna warni. Manusia bukanlah makhluk satu dimensi yang sudah tuntas dirumuskan. Hidup manusia itu tidak saja kaya makna tetapi juga kaya dimensi. Karena itu kita juga tidak akan pernah selesai mendefinisikan seseorang karena ternyata secara spontan kita mesti bertangungjawab terhadap multidimensionalitas manusia dan menentang semua bentuk pengudungan atau pereduksiannya dalam ilmu pengetahuan,ekonomi dan politik. Kita diajak untuk membuang stereotyp aneka wajah mengenai manusia. Doa-doa selama "Reba" yang menuturkan kisah-kisah hidup merelativir segala bentuk penggambaran realitas yang bersifat terlalu hitamputih. Karena mengusung kerahasiaan manusia maka doadoa orang Ngada pada saat "Reba" tidak banyak berhubungan dengan pengetahuan melainkan dengan "keyakinan, harapan dan simpati kepada kehidupan manusia". Doa-doa ini menayangkan pemahaman tentang hakikat manusia,mengenai masalah dan pengalaman- 
pengalamannya dalam upayanya untuk mengenal dan menyempurnakan dirinya dan dunia.

Dalam doa ritus Reba situasi manusia dalam sejarah, dan alam dunia, penderitaan dan kegembiraan,kekuatan dan keterbatasan diangkat kepermukaan sambil sekaligus memberi bayangan mengenai sebuah situasi manusia yang lebih baik (GS art.62). Doa sebagai satu bentuk sastra lisan memang melindungi kedalam hidup manusia baik secara individual maupun secara kolektif. Martabat luhur setiap orang digarisbawahi dalam ritus yang melacak tahap-tahap hidup manusia. Doa mengangkat nilai relasi antara manusia sebagai sesuatu yang sakral. Pada saat orang Ngada berdoa agar ada relasi komunitarian antar manusia "papa dae nee sao lange papa doa nee padhi loka" (hidup berdampingan dengan tetangga dan bersahabat dengan warga sekampung) maka apa yang diperjuangankan itu adalah sebuah "mesu mora" (Cinta kasih) lintas batas. Relasi lintas batas itu sudah tertera dalam paham "sao dhoro" atau kemampuan berbagi kasih yang memang mengikuti beberapa norma humanitarian antara lain:"(1) suu papa suru saa papa laka, sai rengu maru sai zanga sala (berat sama dipikul ringan sama dijinjing, sampai temaram senja,sampai salah menatap), (2) mengakui hak milik pribadi namun tetap ada kesadaran bahwa hak milik tersebut mempunyai fungsi sosial membantu sesama(ngeta baghi ngia mami le mogo), (3) dalam hidup bersama manusia harus mampu menghayati kecerdasan berbagi (tii qa bhai wali wiki, pati qa bhai wali lai), (4) Setiap insan hendaknya memperlakukan sesamanya dengan baik dan lemah lembut,menghargai kesamaan martabat dalam perbedaan (mazi zeta mae kama zeta ,Dewa tuku enga, zale mae kama zale, nitu tuku tange). Watu Y.Vianey (2010: 156).

Pendarasan doa individual dan kolektif memang merupakan bentuk-bentuk penghadiran diri manusia. Doa mereka umumnya sangat spontan dan tanpa kontrol, doa yang lahir dari kondisi keterjepitan, doa yang bernada keluhan yang diucapkan ketika berhadapan dengan ketidakberdayaan manusia, 
memang sering jauh dari pencarian kata-kata yang sudah dipertimbangkan secara matang bobot simbolismenya. Namun demikian kalau kita melihat bentukbentuk doa mereka kita mesti mengatakan bahwa doa itu menyatakan seluruh diri manusia: jeritan,kerinduan,yang menggetarkan jiwa manusia. Doa selama Reba menyatakan sungguh-sungguh sebuah relasi. Tanpa mempunyai hubungan dengan Allah orang tidak mungkin bisa berdoa. Tanpa adanya sebuah relasi yang pernah ada dalam biografi seseorang atau sekelompok orang tidak mungkin doa dapat dinyanyikan dalam nada syukur atau dijeritkan secara bersama-sama sebagai sebuah komunitas. Keseluruhan suasana religius yang tercipta dan terawat setiap tahun di dalam sebuah kolektivitas religius memang dapat menghasilkan doa-doa yang lahir dari pengalaman kolektif. Doa dalam ritus Reba memang mengungkapkan totalitas diri manusia dihadapan realitas yang kudus. Termasuk dalam totalitas manusia itu adalah "nenek moyang dan alam dunia". Karena nenek moyang pun merupakan bagian dari diri,maka tanggungjawab dan keprihatinan atas apa yang dialami sekarang diharapkan menjadi tanggung jawab dan keprihatinan mereka. Kekurangan kita yang hidup tidak perlu menjadi alasan untuk berputus asa karena mereka yang memiliki corak keberadaan yang melampaui keterbatasan akan melengkapi apa yang kurang pada kita.

Pandangan ini memang membuahkan optimisme kolektif dalam menghadapi berbagai persoalan sosial. Dalam doa-doa ritual Reba paham diri holistik manusia menemukan pengungkapannya yang tegas. Seluruh sudut kampung yang biasanya disatukan dalam istilah "ulu-eko" (kepala-ekor) semua yang menjadi warganya dihadirkan sebagai satu diri kolektif yang memerlukan berkat dan perlindungan Tuhan. Doa memang menyapa seluruh diri manusia.Totalitas doa mencakup juga deretan pengalaman, dan cukup jelas selama Reba itu doa tidak hanya bercitra mohon berkat dan rahmat melainkan juga bersyurkur atas semua keberhasilan. Ada lukisan intimitas dengan Allah yang diungkapkan 
dalam keleluasaan untuk menyapa dan kesediaan diri disapa Tuhan dalam situasi gembira Reba.

Dengan demikian, perkembangan kebudayaan tidak terlepas dari peranan manusia sebagai unsur ciptaan yang paling berkuasa. Pendapat ini diperkuat oleh Sidi Gazalba, (1918:74) yang mengatakan bahwa masyarakat adalah wadah kebudayaan lahir dalam masyarakat., masyarakat tumbuh dan bentuk oleh kebudayaan, tidak mungkin ada kebudayaan tanpa masyarakat dan tiap masyarakat melahirkan kebudayaan sendiri. Kebutuhankebutuhan masyarakat tersebut di atas untuk sebagian besar dipenuhi oleh kebudayaan yang bersumber pada masyarakat itu sendiri. Dikatakan sebagian besar karena kemampuan manusia terbatas sehingga kemampuan kebudayaan yang merupakan hasil ciptaannya juga terbatas di dalam memenuhi segala kebutuhan Soekanto, ( 2006:155). Wiliam H. Haviland (Bakker 1990:76) mengatakan kebudayaan adalah seperangkat dan norma yang dimiliki bersama oleh para anggota masyarakat, yang jika dilaksanakan oleh para anggotanya akan melahirkan perilaku yang pandang layak dan diterima oleh masyarakat sedangkan Kupper, (Koentjaraningrat menyatakan bahwa kebudayaan merupakan sistem gagasan dan menjadi pedoman dan pengaruh bagi manusia dalam bersikap dan berprilaku baik secara.

$$
\text { Manusia mempunyai }
$$
berbagai kebutuhan agar dapat menyesuaikan diri dengan lingkungan. Selain itu, kebutuhan manusia muncul sebagai upaya manusia untuk memanfaatkan lingkungan. Dalam suatu kebutuhan terhadap nilai-nilai bagi manusia, nilai dijadikan landasan alasan atau motivasi dalam segala perbuatannya. Dalam pelaksanaan nilai-nilai dijabarkan dalam bentuk norma dan ukuran (normatif) sehingga merupakan suatu perintah atau keharusan, anjuran, larangan.

Karsa masyarakat mewujudkan norma dan nilai-nilai sosial yang sangat perlu untuk mengadakan tata tertib dalam pergaulan kemasyarakatan. Karsa merupakan daya ikatan manusia untuk melindungi diri terhadap kekuatan-kekuatan buruk, manusia 
terpaksa melindungi diri dengan cara menciptakan kaidah-kaidah yang pada hakikatnya merupakan petunjuk-petunjuk tentang bagaimana manusia harus bertindak dan berlaku didalam pergaulan hidup. Kebudayaan mengatur agar manusia dapat mengerti bagaimana seharusnya bertindak, berbuat, menentukan sikapnya kalau mereka berhubungan dengan orang lain Stompka Piotr, (1993:69). Perbuatan atau respon yang mendapat penghargaan dalam situasi yang sama ini akan melahirkan kebiasaan-kebiasaan atau norma-norma, suatu norma juga merupakan hasil pertukaran. Norma adalah suatu statment yang dibuat oleh sejumlah anggota dari suatu kelompok bahwa mereka harus bertingkah laku menurut cara-cara tertentu dalam situasi tertentu. Para pembuat pernyataan ini sadar bahwa perilaku mereka tidak turut serta dalam pembuatan norma memilih apakah patuh dan mendapat penghargaan atau tidak patut dan mendapat hukuman.

Kesamaan-kesamaan nilai dalam masyarakat harus dilandasi dengan kesepakatan-kesepakatan diantara warganya tentang nilainilai dasar bersama. Selain itu perlu pula ada kesepakatan mengangkut cara dengan mana individu memenuhi kehidupannya sebagai elemen normatif masyarakat. Nilai-nilai dan norma dari masyarakat adalah karakteristik budaya dan karakteristik struktur dari masyarakat tersebut dan juga nilainilai norma tersebut adalah rumusan-rumusan bagi tata tertib dan daya rekatnya Sztompka Piotr, (1993:79). Upacara adat pada beberapa suku bangsa di Nusa Tenggara Timur (NTT) yang apabila diperhatikan walaupun mirip antara suku yang satu dengan suku yang lain, tetapi masih ada hal-hal tertentu yang berbeda. Perbedaan ini disebabkan adanya perbedaan adat istiadat, pandangan hidup serta sistem kepercayaan masingmasing suku bangsa yang menyelenggarakan upacara tradisional. Pada umumnya suatu upacara mengandung unsur-unsur sebagai berikut : (1) Nama upacara dalam bahasa daerah. Pengertian nama upacara dalam bahasa Indonesia. (3) Maksud dan tujuan tindakan upacara. (4) Waktu 
penyelenggaraan upacara. (5)

Tempat penyelengaraan upacara.

(6) Penyelenggaraan teknik upacara. (7) Pihak-pihak yang terlibat dalam upacara. (8) Tahaptahap upacara. (9) Jalannya upacara sesuai dengan tahapannya. (10)m Tantangan yang digunakan dalam upacara yang sesuai dengan unsur-unsur. (11) Makna lambang-lambang yang digunakan. (12) Makna upacara secara umum sesuai dengan unsur-unsurnya Depdikbud, (1982/1983 : 24).

Dari pengertian di atas, maka dapat disimpulkan bahwa upacara adalah serangkaian kegiatan atau perayaan yang disusun dan ditaati sedemikan rupa serta sengaja dibuat untuk tujuan tertentu.

1) Ritual Reba

Ritual merupakan suatu kepercayaan masyarakat sejak dari nenek moyang dan diteruskan sampai saat ini, sehingga hal tersebut telah mengikat masyarakat, dan masyarakat beranggapan itu sebuah tradisi. Untuk mengungkapkan makna dan fungsi ritual di atas, maka ada dua klasifikasi ritual yaitu : ritual krisis hidup artinya ritus yang berhubungan dengan krisis hidup manusia. Pada masa ini akan masuk dalam lingkup krisis karena terjadi perubahan tahap hidup, seperti kelahiran, pubertas dan kematian. Upacara Reba bagi masyarakat Luba, Desa Tiworiwu dianggap suatu upacara yang sangat penting karena bertujuan untuk mengingat kembali amanat yang telah ditinggalkan oleh Sili ana wunga. Sili menunjukkan nama orang dan ana wunga artinya anak pertama. Jadi, Sili ana wunga artinya putra pertama atau tokoh pertama yang mengajarkan upacara Reba. Dan pada saat upacara ritual Reba berlangsung, semua keluarga yang menetap di rumah pokok (Sao meze) tidak boleh menyajikan makanan seperti nasi campur dan jenis umbi-umbian, karena menurut adat masyarakat Luba Desa Tiworiwu, makanan yang seperti itu sangat pemali atau tidak lazim dihidangkan untuk dijadikan sesajian atau persembahan bagi para leluhur. Masyarakat Luba yakin bahwa pada waktu semacam itu dahulu telah terjadi peristiwa yang membawa keberuntungan atau kebahagiaan bagi seluruh anggota keluarga, apabila ada 


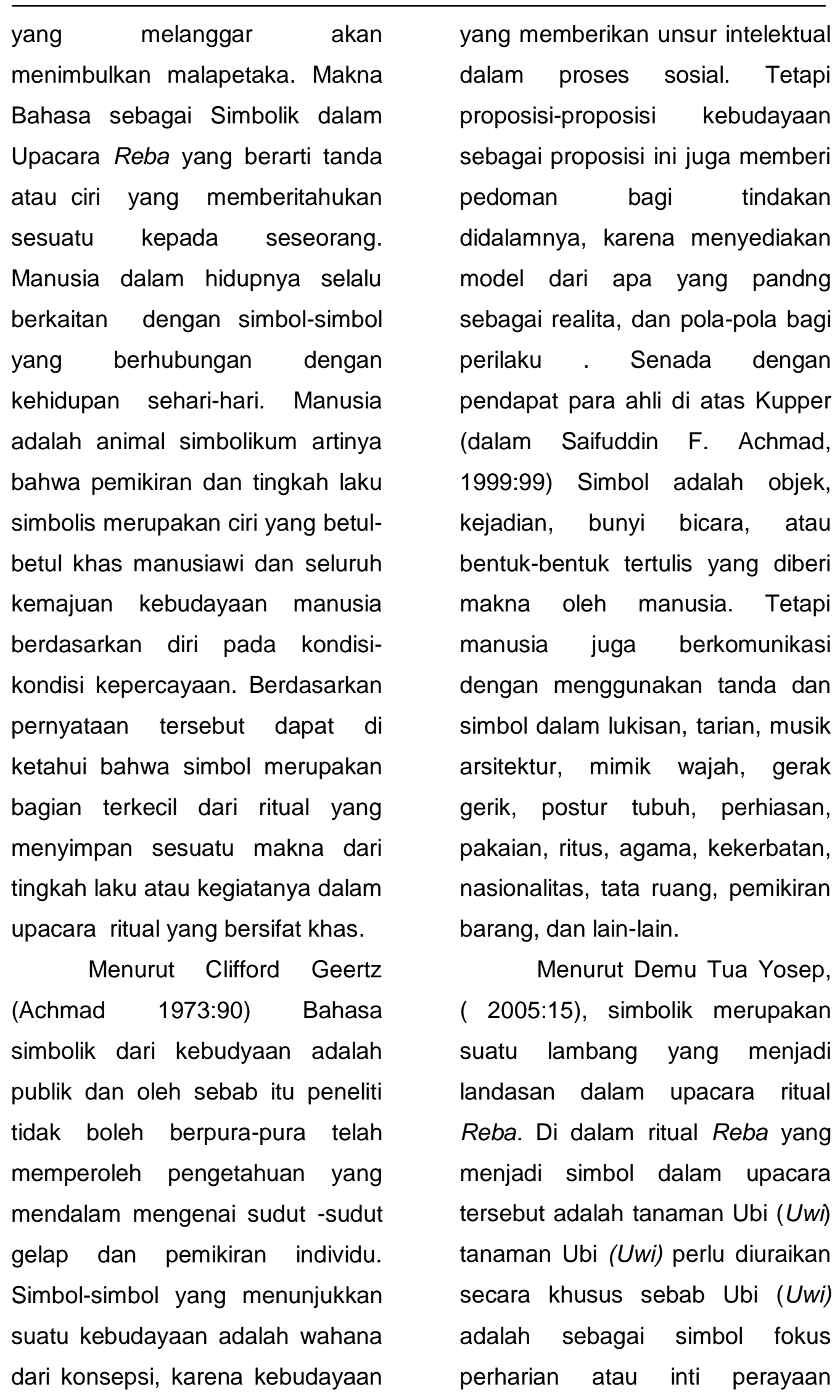


makanan utama yang dilaksanakan pada acara penutupan (Su'i Uwi). Dari pengertian simbolik menurut beberapa para ahli di atas, maka dapat disimpulkan bahwa yang menjadi simbol utama dalam upacara Reba adalah Ubi (Uwi) karena Ubi (Uwi) merupakan sumber kehidupan masyarakat Luba.

Dalam ritual Reba terdapat tiga tahapan kunci yang memperlihatkan pola kehidupan masyarakat Luba adalah sebagai berikut.

1) Acara pembukaan (Kobe Dheke),

Didalam acara ini, sebelum acara berlangsung harus disajikan dengan sepiring nasi, hati babi dan tuak bagi para leluhur yang telah meninggal, sekaligus meminta permohonan serta perlindungan terhadap usaha pertanian dan perkebunan agar memberikan hasil yang berlimpah. Hal tersebut termaksud dalam nilai religius.

2) Acara tari-tarian (Sedo Uwi)

Termasuk dalam nilai moral dimana setiap warga masyarakat mengikuti acara tari-tarian bersama menandakan adanya rasa kegembiraan apa yang mereka sudah peroleh berkat selama setahun sekaligus sebagai tanda saling menghormati dan menjaga kerukunan hidup dalam kehidupan bermasyarakat.

3) Acara penutup (Su'i Uwi

Yang disimbolkan dengan Ubi (Uwi) merupakan sumber kehidupan masyarakat Luba , sekaligus sebagai tanda syukur panen yang mereka peroleh selama setahun. Berdasarkan kerangka berpikir di atas, perayaan Reba dalam masyarakat Luba Desa Tiworiwu II dapat dijelaskan sebagai berikut : Kebudayaan selain sebagai cerminan dan landasan kehidupan bermasyarakat, juga sebagai penghormatan terhadap nenek moyang dengan cara menjadikan apa yang diwariskan mereka sebagai tradisi dan dilaksanakan turun temurun seperti pada tradisi adat masyarakat Luba , dengan merayakan pesta Reba setiap tahun, tepatnya pada bulan Pebruari.

\section{METODE PENELITIAN}

Penelitian ini menggunakan rancangan penelitian deskriptif kualitatif. Penelitian deskriptif dimaksudkan untuk memperoleh 
gambaran yang jelas, objektif, sistematis, dan cermat mengenai fakta-fakta yang diperoleh. Pendekatan metode ini menekankan pada ketajaman analisis secara objektif, sehingga diperoleh ketepatan dalam interpretasi. Subjek penelitian ini adalah Masyarakat Luba Desa Tiwuriwu. Objek dalam penelitian ini adalah simbol bahasa adat dalam ritual Reba Masyarakat Luba. Untuk dapat memperoleh data yang berupa simbol bahasa adat dalam bentuk wawancara. Oleh karena itu, agar dapat memperoleh data yang memadai, peneliti gunakan penjaringan pengumpulan data yakni peneliti menyiapkan bahan dan lembaran wawancara. Topik wawancara diupayakan menarik masyarakat Luba untuk menceritakan dengan bagaimana bahasa adat dalam pelaksanaan ritual adat Reba. Metode dokumentasi adalah suatu cara atau sistem pemberian/pengumpulan, pemilihan, dan pengolahan informasi berdasarkan keteranganketeranngan atau kutipan atau referensi lain (dari bahan-bahan dokumentasi tertulis) yang dapat disajikan terhadap berbagai hal dalam penelitian. Sesuai dengan hal tersebut, metode dokumentasi digunakan oleh peneliti untuk mendapatkan data penelitian di dalam wawancara maupun dokumen tertulis lainnya. Metode deskriptif kualitatif menggunakan beberapa langkah yaitu reduksi data, penyajian, dan penarikan simpulan.

\section{HASIL PENELITIAN DAN PEMBAHASAN}

Dalam penelitian ini, dilaksanakan tanggal 16 Juni 2016 di Desa Tiworiwu. Data tersebut bersumber dari hasil wawancara oleh para tokoh masyarakat yang memahami syair-syair bahasa ritual Reba. Salah satu dari tokoh tersebut adalah Bapak Petrus Tele Ria dan Bapak Yosep Folo sebagai narasumber. Desa Tiwuriwu merupakan suatu desa yang terletak di Kecamatan Jerebuu Kabupaten Ngada. Secara administratif Kabupaten Ngada membawahi Kecamatan dan Kecamatan membawahi Desa. Dilihat dari topografi dan struktur tanah Desa Tiworiwu, secara umum berupa perbukitan, lembah yang berada pada ketinggian kurang lebih 1000 sampai dengan 
1500 meter di atas permukaan dapat diketegorikan daerah yang berealief kasar, karena daerah terdapat sedikit dataran dan kebanyakan terdiri dari bukit-bukit. Oleh karena itu, realiefnya yang seperti ini maka dataran digunakan untuk daerah persawahan, sedangkan bukit-bukit dan lerengnya untuk menanam berbagai jenis tanaman perdagangan seperti kopi, cengkeh, vanili, pisang, kelapa dan beberapa jenis kayu-kayu untuk bangunan seperti ampupu, mahoni dan sengon. Sistem kekerabatan pada masyarakat Desa Tiworiwu ini dibentuk oleh dua faktor yaitu: Faktor keturunan; hubungan kekerabatan ini disebabkan oleh karena berasal dari nenek moyang yang sama, berasal dari keturunan yang sama. Hubungan kekerabatan ini di namakan hubungan adik kakak (kae azi) ini dibentuk oleh satu kesatuan yang disebut (sewoe) kumpulan keuarga yang berasal dari nenek moyang yang sama. Faktor perkawinan; hubungan kekerabatan yang sebabkan oleh karena adanya perkawinan. Hubungan antara keluarga laki-laki dengan keluarga wanita di sebut hubungan ( vai haki) hubungan yang timbal balik.

\section{Pembahasan}

Upacara Ritual Reba adalah rangkaian upacara adat menurut cara dan kebiasaan masyarakat Luba di Desa Tiworiwu yang telah ditinggalkan oleh nenek moyang secara turun temurun. Sebelum pelaksanaan awal ritual Reba berlangsung tuatua adat, anggota suku keluarga (ana woe) ikut serta dalam kegiatan membersihkan pondok kecil (loka) sekaligus memberikan sesajen berupa nasi, hati ayam atau hati babi dan tuak kepada para leluhur.

Berdasarkan hasil wawancara dengan Bapak Petrus Tele Ria (84) dan Bapak Yosep Folo (80 tahun), Jabatan sebagai tokoh adat, (Mosa laki adat) Pekerjaan petani mengatakan bahwa sebelum upacara awal (kobe deke) berlangsung kita harus didahulului membersihkan kintal disekitar pondok kecil (keka lela) yang berada di kebun anggota suku adat. Disekitar pondok kecil (keka lela) ditanami dengan sejenis ubi (uwi), tebu, batu (ture) dan semuanya ini mempunyai makna 
tertentu, yakni: pondok kecil (keka lela) sebagai pelindung, ubi (uwi) sebagai symbol makanan khas orang Ngada, tebu sebagai penopang batang ubi (uwi), sedangkan batu (ture) sebagai simbol perbatasan lokasi tanaman tersebut. Setelah membersihkan kintal, kepala adat atau yang mewakili mulai berdoa dengan mantra sebagai berikut:

Dia ine eu inu tua dia ka maki kena nee ate manu dia kami tii miu da mami miu tii kami da ngeta bho kami koko molo bura gami nee rura bhara woo si gami maa ana ebu miu Diana mona mae dhapa go rio lasa, loka wi lowa peni wi dhesi dai kami nono wai dhepo gami nono logo kasa mae mu ulu mae bana, dia ine ebu inu si tua kena. Artinya: ini nenek moyang mari minum moke ini makan nasi ini dengan hati ayam kami memberi nenek moyang yang masak biar nenek moyang beri kami yang mentah supaya bias bertumbuh dan berkembang, beri kami air liur jauhkan kami dari segala malapetaka, berilah anak cucumu ini berkat yang berlimpah sehingga semua mahkluk peliharaan kami dapat berkembang - biak dengan baik.
Masyarakat Luba adalah masyarakat yang masih berperan teguh pada kebudayaan khususnya pada upacara ritual Reba, dibandingkan dengan masyarakat - masyarakat lain yang berada di kabupaten Ngada. Melihat begitu kompleksnya perkembangan kebudayaan dalam berbagai masyarakat maka kita perlu menyadari hakikat kebudayaan itu sendiri agar tidak mudah melecehkan kebudayaan sendiri ataupun kebudayaan orang lain. Berdasarkan hasil wawancara dengan bapak Lorensius Dolu (60 tahun), jabatan sebagai tokoh masyarakat pekerjaan wiraswasta mengatakan bahwa masyarakat Luba merupakan salah satu contoh masyarakat yang perlu kita meniru. Adapun hal-hal yang perlu kita perhatikan diantaranya sebagai berikut : Pada saat acara ritual Reba berlangsung semua masyarakat yang berada disekitar lokasi mulai dari orang dewasa sampai anak-anak, diwajibkan menggunakan kain adat (lawo). Pada saat acara tari-tarian mereka berlomba-lomba untuk menari bersama. Pada saat acara menyatap bersama mereka tidak menggunakan piring modern dari 


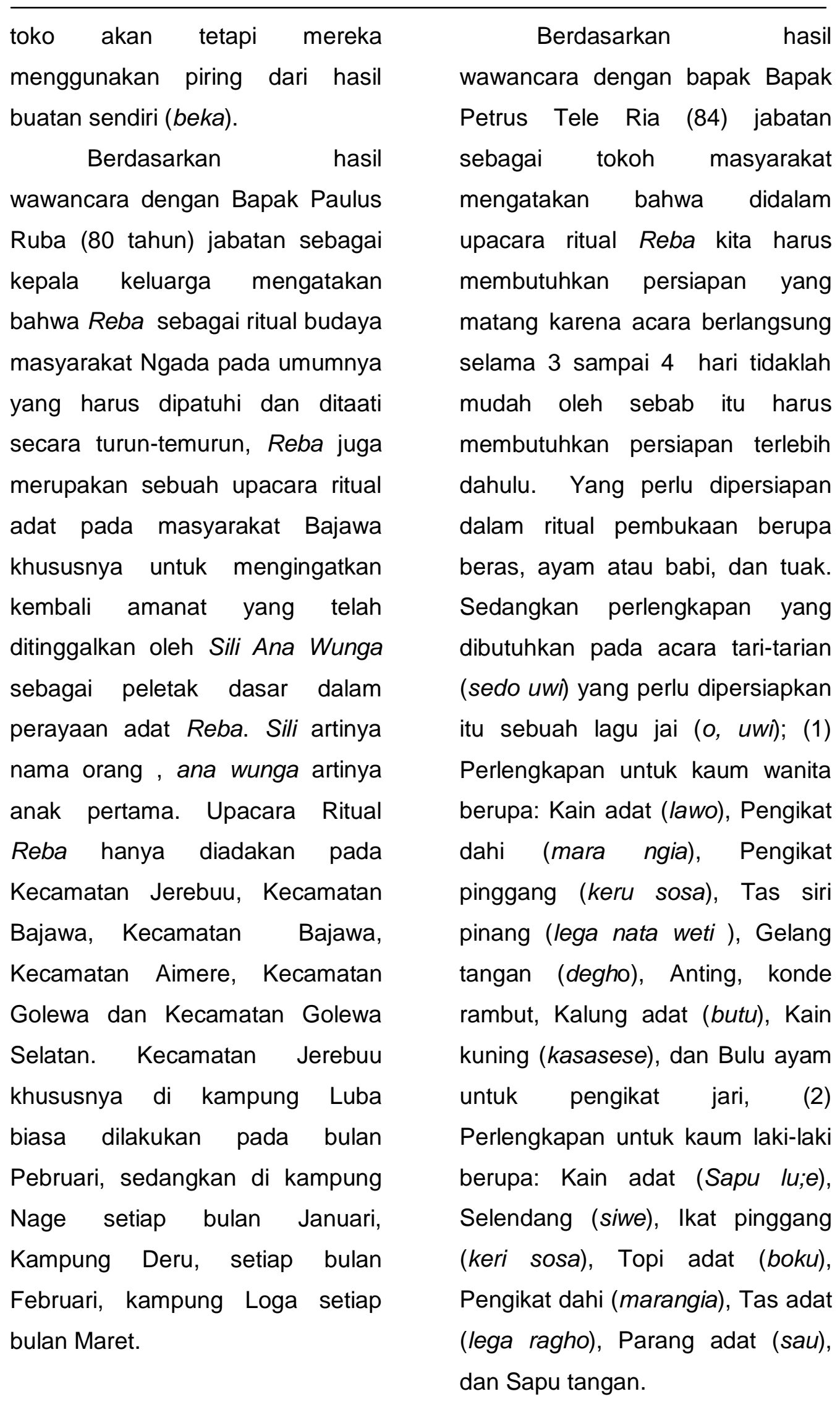


Adapun tata cara upacara ritual Reba terdiri dari beberapa tahap sebagai berikut:

1. Tahap pembukaan (kobe dheke) Berdasarkan hasil wawancara penulis dengan ibu Magdalena Da,e (50 tahun) jabatan sebagai ibu rumah tangga mengatakan bahwa: tata cara pelaksanaan pada acara pembukaan biasanya dilaksanakan pada malam hari dan acara ritual adat tersebut harus dilakukan di rumah pokok (sao meze) pukul 07.00 - selesai.

Dimana yang menjadi pusat penelitian penulis yang merupakan kesempatan yang dinantikan oleh keluarga baik yang merantau maupun yang berada dalam kampung sendiri harus hadir. Setiap acara pembukaan yang dilakukan pada malam hari presentase kehadiran keluarga sangat besar, kehadiran mereka inilah sangat berdampak pada pergaulan karena pada acara pembukaan (Kobe Dheke) merupakan acara yang bahagia antara satu dengan yang lain mulai menceritakan pengalaman masingmasing. Pada dasarnya dalam ritual Reba terdapat tiga tahap kunci yang memperlihatkan pada pola kehidupan masyarakat Luba yaitu:

2. Tahap tari-tarian (sedo uwi)

$\begin{array}{lrr}\text { Acara } & \text { tersebut yang } \\ \text { menandakan adanya rasa } & \\ \text { kegembiraan karena apa yang } \\ \text { sudah mereka peroleh berkat } \\ \text { selama setahun , sekaligus } \\ \text { sebagai tannda raling }\end{array}$
menghormati serta menjaga kerukunan dalam kehidupan bermasyarakat

3. Tahap penutup (sui uwi) Merupakan simbol sumber kehidupan masyarakat setempat, sekaligus sebagai tanda syukur panen yang mereka peroleh selama setahun. Bagaimana kalau ada kesalahan yang dilakukan pada tahap pembukaan (kobe dheke). Kalau ada kesalahan pada tahap pembukaan itu, kita tidak akan mendapat musibah atau malah petaka karena para leluhur menyerti terhadap anak cucunya mungkin ada kekeliruan atau tidak dengan sengaja mereka berbuat. Bagaimana jika tidak dilakukan ritual pembukaan (kobe dheke), apabila tidak dilakukan acara pembukaan ini maka kita akan mendapat musibah dari para leluhur, misalnya semua hasil peliharaan kita tidak berkembang 
biak, kita menderita sakit, menderita kelaparan, pendidikan tidak berjalan dengan lancar dan lain sebagainya. Mengapa harus ada ritual pembukaan (kobe dheke). Karena ritual pembukaan itu merupakan kegiatan inti untuk memberi jalan kepada seluruh anak cucu sehingga dapat berkumpul bersama didalam rumah pokok (sao meze) supaya saling membagi kasih antara satu dengan yang lain karena selama setahun mereka berpisah. Bagaimana tata cara pelaksanaan pada tahap penutupan (sui uwi). Tata cara pelaksanaan pada acara penutupan itu, semua rumpun keluarga harus wajib hadir karena pada tahap penutupan merupakan acara untuk menutup pintu, sekaligus kepala adat atau yang mewakili membicarakan hal-hal penting yang menyangkut adat.

\section{PENUTUP}

Ritual Reba merupakan sebuah acara yang patut dilaksanakan selama setahun sekali dan perlu ditaati sejak dari nenek moyang pada zaman dahulu kala dan harus terbawa terus sampai anak cucu. Apabila kita sia-siakan ritual Reba ini maka segala usaha kita tidak akan terkabul oleh perlindungan leluhur, karena leluhur inilah yang membentuk budaya ritual Reba sehingga dikembangkan oleh generasi - penerus. Dengan adanya upacara Reba dapat mengingatkan pesanan yang ditinggalkan oleh leluhur (Sili Ana Wunga) sebagai pioner pertama penyelenggaraan budaya Reba. Perayaan adat Reba merupakan upacara ritual magis karena seluruh tahapan upacara Reba wajib didahului dengan pemberian sesajen Roh arwah leluhur agar dapat menguasai alam sehingga perayaan Reba dapat berjalan dengan baik.

Dalam upacara Reba akan dirayakan relevan dengan kalender, yang dirayakan dalam setahun sekali. Secara sitematika perayaan upacara ritual Reba terdapat tiga tahap perayaan inti yaitu : Kobe Dheke "acara pembukaan "Sedo Uwi "acara taritarian " dan Sui Uwi "penutupan upacara". Dari ketiga tahap perayaan inti tersebut jika ada yang melanggar akan menimpa musibah karena diantara tiga tahap perayaan inti terebut mengandung nilai-nilai kebudayaan yaitu : nilai 
religius, filosofis,kesenian, moral, magis, ekonomi, sosial, hukum dan pendidikan. Nilai-nilai inilah sangat dipatuhi dalam upacara Reba untuk mengikat rasa solidaritas dalam kehidupan bermasyarakat.Oleh sebab itu ritual Reba ini haru dipertahankan bagi mayarakat penganutnya karena ritual Reba ini harus dipertahankan bagi masyarakat penganutnya karena ritual Reba sebgai upacara adat yang dibangun dan ditumbuhkembangkan oleh generasigenerasi sehingga tidak dimusnahkan. Oleh karena itu, tuatua adat dapat memberikan motivasi kepada masyarakat Luba untuk lebih aktif belajar menghargai dan menaati sesuai dengan tahap-tahap ritual Reba yang berlaku. Untuk mengembangkan upacara Reba maka bagi generasi-generasi penerus harus berperan aktif dalam setiap upacara Reba agar lebih matang dalam setiap tahap perayaan adat Reba. Dengan kelancaran dan kesuksesan dalam upacara ini, pemerintah turut berpartisipasi dalam setiap perayaan Reba dan dapat memberikan motivasi kepada masyarakat agar lebih memahami arti pentingnya ritual Reba yang diajarkan sejak dari nenek moyang pada zaman dahulu kala, sehingga masyarakat dapat belajar dengan lebih kreatifitas dan pada akhirnya akan memperoleh berkat dari para leluhur.

\section{REFERENSI}

Antony Bagul Dagul, 1995. Bahan Seminar Norma dan Nilai Adat dalam Proses Pendidikan Masyarakat Kabupaten Manggarai. Penerbit: UBHARA PRESS. Surabaya.

Arnicum Azis, Hartono. 2001. IImu Sosial Dasar. Bumi Aksara Jakarta..

Amram, H. 1976. Kamus Umum Bahasa Indonesia. Pustaka Baru, Jakarta.

Bankker, J.M.W, 1990. Filsafat Kebudayaan Suatu Pengantar. Jakarta: Kanisius.

Demu Tua Yosep, 2005. Reba. Perpustakaan Provinsi NTT.

Depdikbud. 1983. Upacara Tradisional NTT. Proyek Infentarisasi dan Dokumentasi Daerah, Kupang.

Djojodigoeno, M. 1958 Asas-asas Sosiologi. Jakarta:Balai Pustaka 
Koentjaraningrat. 1976. Manusia dan Kebudayaan di Indonesia. Djambatan Jakarta.

Medan, Kopong, dkk. 2005. Budaya Lamaholot dan Perakit Penyelesaian Sengketa

Soekanto, S. 2006. Sosiologi Suatu Pengantar. PT. Raja Grafindo Persada Jakarta.
Sae, M (2005) Masyarakat Langa Menggelar Pesta Reba. Flores Pos UPTD Arkeologi, Sajian Sejarah dan Nilai Tradisional

Provinsi NTT Kupang. Upacara Soka Ju (Tolak Bala) di kelurahan Wojojitu Kecamatan Wolojitu Kabupaten Ende.

Zamzani. 2007. Kajian Sosiopragmatik. Yogyakarta: Cipta Pustaka. 